\title{
Optimization of Controller for Microbial Fuel Cell: Comparison between Genetic Algorithm and Fuzzy Logic
}

\author{
Li-ping Fan ${ }^{1,2 *}$, Xiao-min Chen ${ }^{1,2}$ \\ ${ }^{1}$ College of Information Engineering, Shenyang University of Chemical Technology, Shenyang, \\ 110142 China \\ ${ }^{2}$ Liaoning Key Laboratory of Industry-Environment-Resource Collaborative Control and Optimization \\ Technology, Shenyang University of Chemical Technology, Shenyang 110142, China \\ *E-mail: flpsd@163.com
}

Received: 17 July 2021 / Accepted: 3 September 2021 / Published: 10 October 2021

\begin{abstract}
Microbial fuel cell (MFC) has attracted more and more attention as a kind of efficient and green power source. Due to its own complexity, the precise control of MFC is still difficult to achieve. The output voltage of MFC has large overshoot and shock under traditional PID control, and it is difficult to adapt to the changes in operating conditions. So, a genetic algorithm optimized fuzzy PID control is proposed to improve the controller effect and realize the constant voltage output control of the MFC. Simulation results show that compared with the traditional PID, the genetic algorithm optimized PID, and the fuzzy tuning PID, the genetic algorithm optimized fuzzy PID control shows smaller overshoot, better stability and stronger anti-interference ability. Optimizing the conventional PID through fuzzy logic and genetic algorithm is a simple, easy, low-cost but effective method to solve the problems of unstable power generation and poor anti-interference ability of MFC system.
\end{abstract}

Keywords: microbial fuel cell(MFC); genetic algorithm; fuzzy control

\section{$\underline{\text { FULL TEXT }}$}

(C) 2021 The Authors. Published by ESG (www.electrochemsci.org). This article is an open access article distributed under the terms and conditions of the Creative Commons Attribution license (http://creativecommons.org/licenses/by/4.0/). 